\title{
Albert Lemoine and the epistemology in psychiatry
}

\section{Albert Lemoine e a epistemologia da psiquiatria}

German E. Berrios*

In 1862, the French philosopher Albert Lemoine (1824-1874) published one of the earliest books on the philosophy of psychiatry and psychopathology. Although brought up as a Spiritualist thinker in the mould of Maine de Biran and Royer-Collard, he attempted to reconcile the speculative neurobiological account of madness predominant in his time (particularly amongst alienists interested in its medicalization) with a broader approach that conceived of the mind as a psychological space populated by dynamic forces and elements also relevant to the causality and meaning of madness. In the ongoing debate on whether Psychology or Physiology was the most appropriate science for the study of Madness he rightly stood in the middle. His views remain important for the issues that he dealt with have not yet been resolved.

Key words: Psychiatry, epistemology, Lemoine, $19^{\text {th }}$ century, France, philosophy, conceptual analysis

* University of Cambridge (Cambridge, UK). 
This Classic Text that follows is the first chapter of a book on the philosophy of psychiatry written by Albert Lemoine (1862), a $19^{\text {th }}$ century French philosopher whose early death deprived French philosophy of a competent and versatile thinker.

\section{The man}

Jacques Félix Albert Lemoine was born in $8^{\text {th }}$ Abril 1824 in Paris. After schooling at the College Charlemagne in 1844 he achieved $8^{\text {th }}$ place amongst 18 entering L'École Normale Supérieure and was awarded a half-scholarship. Graduating second in the final examination he obtained his aggregation in 1847. He was philosophy teacher at the Lycée de Nantes until 1853. In 1850 he had graduated doctor ès-lettres with a thesis on Charles Bonnet. He also won a competition organized by the Academy of Moral and Political Sciences on the subject of 'sleep'. After teaching philosophy at the Lycée Bonaparte until December 1854 he got his first University professorship at Nancy. After teaching at Bordeaux again he returned to Paris, first at the Lycée Condorcet and finally at L'École Normale Supérieure (Franck, 1875). In 1852 he married Adele Picard.

In addition to his early publications on Charles Bonnet (1850) and on Sleep (1855), Lemoine published a book on Vitalism and Animism in Stahl (1858), The madman from the perspective of science, ethics and society (1862), The soul and the Body (1862), Physiognomy and speech (1865), and a posthumous on Habit (1875). On account of bad health 


\section{CLÁSSICOS DA PSICOPATOLOGIA}

in 1872 he resigned from his lecturership at L'École Normale Supérieure and was appointed Inspector of Paris Academies. Lemoine died on 25 September 1874 (Drouin-Hans, 1995) after failing five times in his effort to become a member of the Paris Academy of Moral and Political Sciences. He wrote during a historical period when both French philosophy and Alienism (Psychiatry) were moving rapidly and this conferred upon his work a dynamic quality. Although a conservative writer, his effort to find a via media exposed him to a bilateral critique (Franck, 1875). He participated in various national debates including the important one on 'habitude' (Sinclair, 2017).

\section{The philosophical background}

At the beginning of the $19^{\text {th }}$ century there were three distinguishable philosophical schools in France (Mead, 1936): Sensualism (Condillac's personal interpretation of the ideas of John Locke) (Thiel, 2015) which was divided into two strands: 'physiological' (Cabanis et al.) (Staum, 1980) and 'ideological' (Destutt de Tracy et al.) (Picavet, 1891). Opposed to Sensualism there were the Theological (Bonald, de Maistre and Lammenais) and Spiritualist (Royer-Collard, Maine de Biran, and Theodore Jouffroy) schools (Janet \& Séailles, 1899). After the 1820s, Victor Cousin tried to bring these ideas together into a form of "Eclecticism" (Janet, 1885). Lemoine aligned himself with the Spiritualist school (Janet, 1879) although from the start he showed interest in the Cartesian relationship between mind and body. At the time this old issue was included in the debate on whether psychology or physiology (Maine de Biran, 1887; Jouffroy, 1872) was most appropriate to deal with mind (Janet, 1867) (and madness). Essential to understanding this debate is the metaphysics of Cartesianism.

\section{Cartesianism}

In the middle of the $17^{\text {th }}$ century, Descartes stated that there were three substances: God (increated and infinite), soul or mind (res cogitans: created, immaterial and thinking) and body (res extensa: material and extended). Descartes's epistemological and metaphysical proposal has both helped and hindered research (Radner, 1971). It freed the human body from religious 
control and encourage anatomical and physiological research. Although Descartes believed that, in practice, mind and body interacted freely the manner of this interaction has remained a hard problem in the philosophy of mind. To resolve it various solutions have been proposed: 1. claim that the mind is not a substance but just an emergent epiphenomenon or name for a property of matter (Reductionism); 2. state that the body is just a product of the mind (Idealist solution); 3. The mind and the body do not interact at all but chime at the unison like two clocks (pre-established harmony); and 4. mind and body name two properties of a unique material substance (neutral monism). Nowadays the favoured solutions are 'Neutral monism' (Banks, 2010) and Reductionism (Bickle, 2003).

\section{Cartesian dualism and madness}

After being out of fashion during the Enlightenment, Descartes philosophy made a return during the 19th century. In France, Dégerando, Laromiguière, Maine de Biran, Royer Collard, Cousin, etc., were closer to Descartes's ideas than their criticisms might let out. Alienists were part of this ferment. Esquirol attended Laromiguière's lectures and knew of Dégerando's work; Antoine-Athanase Royer-Collard, was brother of Pierre Royer-Collard, the philosopher; and Maine de Biran's ideas were built into the later development of French Alienism (Goldstein, 2002; Swain, 1978; Swain, 1977).

The impact of Descartes on 19th century German Philosophy was part of the Neo-Kantian revival (Schlösser, 2015). Kant seems to have read only some of Descartes's work and there is agreement that his criticism of Descartes' cogito is not altogether correct. "The Marburg School neo-Kantians regarded Descartes as a historical predecessor of Kant. Natorp presented in 1882 a Kantian-type study of the essential Cartesian themes in his 'Descartes 'Erkenntnistheorie' (Descartes's Epistemology); Hermann Cohen praised especially Descartes's philosophical contribution to the founding of a "mathematical science"; Cassirer examined in his doctoral dissertation of 1899 Descartes's epistemological foundation of mathematics and science" (Holzhey \& Mudroch, 2005, p. 102).

In Great Britain, Cartesianism fared differently in Scotland and England. Thomas Reid and other members of the so-called Scottish Philosophy of Common Sense opposed 'the way of ideas', an epistemological model that they attributed to Locke and Descartes: "Reid argued that the accounts of 


\section{CLÁSSICOS DA PSICOPATOLOGIA}

Descartes, Locke, and Berkeley fail to explain our acquisition of primary quality concepts. Reid plugs the gap with an appeal to natural signs" (Nichols, 2007, p. 108). In England, things are somewhat more complicated for throughout the 19th century various philosophical doctrines vied for dominance. Descartes is barely mentioned in the work of Bentham, the Mills, Grote, Maurice, Newman, Martineau and Spencer (Sorley, 1920). However, Cartesianism reappeared after the late introduction of Neo-Hegelianism (started with Stirling, 1865) and was incorporated into some forms of British Idealism (Mander, 2011).

The conceptual options for Cartesian dualists writing on madness were a copy of those proposed by philosophers: a) accept or deny that the two substances (mind and brain) communicate in some part of the brain; b) reduce mental illness to being just a disease of the brain; and c) redefine mental illness as a symbolic conflict occurring in a new space (whether psychological, intersubjective or linguistic). ${ }^{1}$ These options have been tried in practice: a) brain disease causes madness simpliciter (neuropsychiatry); b) there is a symmetrical interaction (psychosomatic medicine and 'psychogenesis'), and c) there is no interaction but some sort of functional parallelism, harmony or concomitance between mind and brain (J. H. Jackson).

\section{Conventional Neuropsychiatry}

The view that changes in the brain can lead to madness (Wickens, 2015; Lanteri-Laura, 1984) is based on age-old observations that injuries to the head, ingestion of toxic substances, and inborn brain malformations are associated with changes in mind, awareness and behaviour (Hollander, 1910; Smith, 2014). By the early 19th century, this view provided one of the main arguments for the medicalization of madness. Not everyone agreed with this direct causality model. Writers holding the religious belief that the mind (soul, spirit) was not susceptible to disease challenged the claim that the mental symptoms observed in patients suffering from acute brain disease

${ }^{1}$ Talking to psychiatrists Heidegger stated: "The Justification of Psychology consists only in its point of departure and in its taking the noncorporal seriously..." (Heidegger, 2001, p. 216). 
were identical phenomena as those seen in real madness (insanity, lunacy, alienation etc). For example, at the beginning of the $19^{\text {th }}$ century there was a debate on whether the hallucinations experienced by Nicolaï, the Berlin bookseller, were the same as those reported by the madman Berbiguier (Berrios \& Marková, 2015). Baillarger (1890) also differentiated between 'psychic' and 'psycho-sensorial' (organic) hallucinations. Indeed, the debate has continued well into the $20^{\text {th }}$ century between a unitary and binary view, namely, whether the psychotic psychopathology of schizophrenia or manic-depressive disease is the same as that seen in patients with brain tumours, Parkinson's or Huntington's disease, epilepsy, dementia etc. (Berrios \& Dening, 1990; Berrios \& Marková, 2012).

\section{Psychosomatic Medicine and 'Psychogenesis'}

Although as an organized specialism Psychosomatic medicine is only identifiable during the $20^{\text {th }}$ century, the question of whether stress in the mind and emotions can produce pathological changes in the body is much older and can be found throughout history (Martin, 1978). For example, there are pre-Freudian (Tuke, 1873), Freudian (Nemiah, 2000; Alexander, 1950), and Post-Freudian (Uexküll, 1997) psychosomatic forms of explanation. Originally only a concern for medical experts such as cardiologists, gastroenterologists and dermatologists, after the Freudian revolution psychosomatic issues also became of interest to alienists. This explains why the relationship between psychosomatic medicine and psychiatry is not uniform throughout the world. In the USA for example, the American Psychiatric Association considers psychosomatic medicine as a sub-specialism of psychiatry; in Germany and France it does constitute an independent specialism practiced by physicians; and in the United Kingdom is almost non-existent.

The concept of 'psychogenesis' is central to psychosomatic medicine and psychiatry. Unfortunately, both its meanings have gone out of fashion (Lewis, 1972). Since before the $19^{\text {th }}$ century 'Psychogenesis' referred to the process whereby the soul (and later the mind and personality) were constructed (Fountopoulos, 1924; Morgan, 1892; Dide, 1926). During the $19^{\text {th }}$ century 'psychogenesis' started to name the mechanism whereby the mind can generate mental disorder (Jung, 1960; Cossa, 1969; Birnbaum, 1923; Ey, 1950; Berrios, 2003). Sommer used the word "Psychogenie" to name a subgroup of disorders that hitherto had fallen under the collective name 


\section{CLÁSSICOS DA PSICOPATOLOGIA}

hysteria. ${ }^{2}$ The mechanisms explaining 'psychogenesis' have also changed according to the psychological theory in fashion. They can act directly on the body or via structures such as the personality. Of late, efforts have been made to naturalize the concept of psychogenesis, i.e. to identify its underlying brain mechanisms (Dimitriadis, 2013).

\section{J. H. Jackson and 'Concomitancy'}

John Hughlings Jackson borrowed his philosophy of mind from Fisk, Spencer and Clifford (Berrios, 2001; Jacyna, 2011) and went on to influence Janet, Freud, Ribot, Dumas, and Ey (Dewhurst, 1982). Jackson believed that the 'mind' had no capacity to influence anything so a symmetric causal interaction with the body was out of the question. Mental and body phenomena were to be considered as 'concomitant' or 'parallel' to each other: "The late Professor Clifford wrote: I may very well say that among the physical facts which go along at the same time with mental facts, there are forces at work. That is perfectly true, but the two things are on utterly different platforms, the physical facts go along by themselves, and the mental facts go along by themselves. There is a parallelism between them, but no interference of one with the other" (Jackson, 1932, p. 355).

Likewise, in the Croonian lectures: "The doctrine I hold is: first, that states of consciousness (or, synonymously states of mind) are utterly different from nervous states; secondly, that the two things occur together - that for every mental state there is a correlative nervous state; third, that, although the two things occur in parallelism, there is no interference of one with the other. This may be called the doctrine of concomitance. Thus, in the case of visual perception there is an unbroken physical circuit, complete reflex action, from sensory periphery through highest centres back to muscular periphery. The visual image, a purely mental state, occurs in parallelism with - arises during (not from) - the activities of the two highest links of this purely physical chain; so to speak, it 'stands outside' these links. It seems to me that the

2 "Unter dem Namen „Psychogenie“ möchte ich eine bestimmte, praktisch wichtige Gruppe von Krankheitsfällen aus dem grossen Gebiete herausheben, welches man mit dem Sammelnamen Hysterie zusammenfasst" Sommer (1894, p. 125). 
doctrine of concomitance is, at any rate, convenient in the study of nervous diseases.

\section{The Classic Text}

The conceptual kernel of Lemoine's text is summarized in his pointed questions: "A first question naturally arises in the mind of the physiologist or the psychologist: Is madness a bodily disease, or is it, according to the consecrated expression taken rigorously and literally, a 'mental illness'? Is it an evil that primarily strikes the body or directly the mind? Is a disease of some organ, e.g. the brain, or is it a disease of the 'soul'? Is a madman a patient like any other, like a man suffering from a cerebral fever; or is it only a mind that is mistaken, like in the case of a fool who makes a gross error of judgment or reasoning? Does madness have its seat, is its venue exclusively in the body or in the mind?". 3

Lemoine wanted to debate the nature and aetiology of madness against the views of $19^{\text {th }}$ century French Alienists who by then mostly sponsored a speculative neuroscientific view. He sought the support of Françoise Leuret, one of the few alienists that disagree with the official line (Leuret, 1851). However, his question was more conceptual than empirical for, as a spiritualist philosopher in the mould of Royer-Collard, he still wondered whether the mind could become diseased. Ravaisson put this very clearly: "Most of the writings in which this subject has been treated emanate from physiologists who have endeavoured to demonstrate that thought is a function of the brain; that madness is an alteration of this function, resulting from some

3 "Une première question se propose naturellement à l'esprit du physiologiste ou du psychologue: La folie est-elle une maladie corporelle, ou est-elle rigoureusement, seIon l'expression consacrée prise à la lettre, une maladie mentale? Est-ce un mal qui frappe immédiatement le corps ou qui afflige directement l'esprit? Une maladie de quelque organe, du cerveau par exemple, ou une maladie de l'âme? Un fou est-il un malade comme un autre, comme un homme atteint d'une fièvre cérébrale; ou bien n'est-ce qu'une intelligence qui se trompe, comme celui qu'on appelle aussi un insensé, parce qu'il commet une erreur grossière de jugement ou de raisonnement? La folie a-t-elle son siégé, son principe et son foyer exclusif dans le corps ou dans l'esprit?" (Lemoine, 1862, pp. 27-28). 


\section{CLÁSSICOS DA PSICOPATOLOGIA}

material damage ..." M. Albert Lemoine, in L'aliéné devant la science et devant le société" has defended the opposite thesis. Recognizing the principle that thought is entirely independent of the body, he does not want madness to accord with this principle; he does not want the mind to be ill. Lemoine agrees with the materialists, of whom he is in all respects the declared adversary, in attributing the origin of madness to lesions of the nervous system. Does madness often originate from moral causes? According to him, these cause a disorder of the brain which leads to a disorder of the senses and imagination. In his opinion, reason cannot be injured". ${ }^{4}$

The debate on these issues continues. The point of this Classic Text is to show that writers who try to reconcile antagonistic positions in regard to the aetiology of madness have always a hard time. Indeed, it is easier to side with either the reductionistic or mentalistic view of madness and in our day this polarization remains a popular choice. It is more difficult simultaneously to claim, as Lemoine did that: 1) although madness may often enough be related to disturbances of the brain 2) such association by itself explains little and often is not useful to develop adequate therapies; and this because 3) the real drama of madness does not take place in the brain as such but in a psychological (intersubjective, semantic) space where interacting symbols, allegories and cultural configurations determine the final clinical profile of madness. It is unfortunate that the reality of this space is currently being called into question, that psychogenesis has become an empty word, and that we are no longer looking for therapeutic solutions in the most human of territories, that of language and intersubjectivity (Berrios, 2015; Berrios \& Marková, 2015).

4 "La plupart des ouvrages où a été traité ce sujet émanent de physiologistes qui se sont efforcés de démontrer que la pensée est une fonction du cerveau; que la folie es une altération de cette fonction, résultant de quelques lesión matérielle ..." "M. Albert Lemoine, dans L'aliéné devant la science et devant la Société, a soutenu une thèse tout oppose. Reconnaissant un principe de la pensée entièrement indépendant du corps, il ne veut pas que la folie puisse atteindre ce principe; il ne veut pas que l'âme puisse être malade ... Lemoine s'accorde donc avec ces matérialistes, dont il est à tous égards l'adversaire déclaré, pour atribuir l'origine de la folie à des lésions du système nerveux. Dira-t-on que la folie semble provenir souvent de causes uniquement morales? C'est, selon lui, que ces causes produisent dans le Cerveau un désordre dont se ressentent consécutivement les sens ou l'imagination. Mais la raison ne saurait être, à son avis, ni consécutivement ni originairement lésée..." (Ravaisson, 1882, pp. 209-210). 


\section{References}

Alexander, F. (1950). Psychosomatic Medicine. New York: Norton.

Baillarger, J. (1890). De la nature des hallucinations. In Recherches sur les Maladies Mentales (Vol. 1, pp. 377-394). Paris: Masson.

Banks, E.C. (2010). Neutral Monism reconsidered. Philosophical Psychology, 23, 173-187.

Berrios, G. E. (2001). The Factors on Insanity and J Hughlings Jackson. History of Psychiatry, 12, 353-373.

Berrios, G. E. (2003). Foreword. In A. Wimmer. Psychogenic Psychoses. (Translated by J. Schioldann, pp. 9-15). Adelaide: Adelaide Academic Press.

Berrios, G. E. (2015). The role of Cultural Configurators in the formation of mental symptoms. In K. Kendler, \& J. Parnas (Eds), Philosophical Issues in Psychiatry III (pp. 107-115). Oxford: Oxford University Press.

Berrios, G. E., \& Dening, T. R. (1990). Biological and Quantitative Issues in Neuropsychiatry. Behavioural Neurology, 3, 247-259.

Berrios, G. E., \& Marková, I. S. (2012). The Construction of Hallucinations. In J. D. Blom, \& I. E. D. Somner (Eds). Hallucinations: Research and Practice (pp. 55-71). Berlin: Springer.

Berrios, G. E., \& Marková, I. S. (2015a). Toward a New Epistemology of Psychiatry. In L. J. Kirmayer, R. Lemelson, \& C. A. Cummings (Eds.), Re-Visioning Psychiatry (pp. 41-64). Cambridge: Cambridge University Press.

Berrios, G. E., \& Marková, I. S. (2015b). Visual Hallucinations: history and context of current research. In D. Collerton, U. P. Mosimann, \& E. Perry (Eds.). The Neuroscience of Visual Hallucinations (pp. 3-22). London: Wiley.

Bickle, J. (2003). Philosophy and Neuroscience. A ruthlessly reductive account. Berlin, Springer.

Birnbaum, K. (1923). Der Aufbau der Psychose. Grundzüge der Psychiatrischen Strukturanalyse. Berlin: Springer.

Cossa, P. (1969). Organogenèse ou psychogenèse des troubles mentales. Bulletin de L'Académie Nationale de Medicine, 153, 345-348.

Dewhurst, K. (1926). Hughlings Jackson on Psychiatry. Oxford: Sanford Publications, 1982. Dide, M. Introduction à l'étude de la Psychogénèse. Paris: Masson.

Dimitriadis, Y. (2013). Psychogénèse et organogénèse en psychopathologie. Paris: L'Harmattan. 


\section{CLÁSSICOS DA PSICOPATOLOGIA}

Drouin-Hans, A. M. (1995). L'epistemologie d'Albert Lemoine (1824-1874). Romantisme, 88, 75-84.

Ey, H. (1950). Le problème de la psychogénèse des névroses et des psychoses. Paris: Desclée de Brouwer.

Fountopoulos, A. (1924). La psychogénèse ou la naissance de l'âme humaine. Paris: Gamber.

Franck, M. A. (1875). Dictionnaire des Sciences Philosophiques. Paris: Hachette.

Goldstein, J. (2002). Console and Classify: The French Psychiatric Profession in the Nineteenth Century. ( $2^{\text {nd }}$ Ed.). Chicago: University of Chicago Press.

Heidegger, M. (2001). Zollikon Seminars. Edited by Medard Boss. Evanston: Northwestern University Press.

Hollander, B. (1910). The Mental Symptoms of Brain Disease. London: Rebman.

Holzhey, H., \& Mudroch, V. (2005). Historical Dictionary of Kant and Kantianism. Oxford: The Scarecrow Press.

Jackson, J. H. (1932). 'On the comparative study of diseases of the nervous system'. In J. Taylor (Ed.), Selected Writings of John Hughlings Jackson (Vol. II, pp. 393410). London: Hodder \& Stoughton.

Jacyna, L. S. (2011). Process and Progress: John Hughlings Jackson's Philosophy of Science. Brain, 134: 3121-3126.

Janet, P. (1867). Le cerveau et la pensée. Paris: Baillière.

Janet, P. (1879). La Philosophie Française Contemporaine. Paris: Lévy.

Janet, P. (1885). Victor Cousin et son æevre. Paris: Lévy.

Janet, P., \& Séailles. G. (1899). Histoire de la Philosophie. (3 ${ }^{\text {rd }}$ Ed.). Paris: Delagrave. Jouffroy, T. (1872). Nouveaux Mélanges Philosophiques. Paris: Hachette.

Jung, C. G. (1984). The Psychogenesis of Mental Disease. Bollinger Series, Princeton: Princeton University Press, 1960.

Lanteri-Laura, G. La laïcisation du Cerveau: charnière des XVIIIe et XIXe siècles. Psychologie Médicale, 16, 993-1002.

Lemoine, A. (1862). L'aliéné devant la philosophie, la morale, et la Société. Paris: Didier.

Leuret, F. (1840). Du traitement moral de la folie. Paris: Baillière.

Lewis, A. (1972). "Psychogenic": a word and its mutations. Psychological Medicine, 2, 209-215.

Maine de Biran (1887). Science et Psychologie. Paris: Leroux.

Mander, W. J. (2011). British Idealism. A History. Oxford: Oxford University Press.

Martin, M. J. (1978). Psychosomatic Medicine. A Brief History. Psychosomatics, 19, 697-700. 
Mead, G. H. (1936). Movements of Thought in the Nineteenth Century. Chicago: The University of Chicago Press.

Morgan, C. L. (1892). The Law of Psychogenesis. Mind, 1, 72-93.

Nemiah, J. C. (2000). A psychodynamic view of psychosomatic medicine. Psychosomatic Medicine, 62, 299-303.

Nichols, R. (2007). Thomas Reid's Theory of Perception. Oxford: Clarendon Press.

Picavet, F. (1891). Les Idéologues. Paris: Alcan.

Radner D. Descartes' Notion of the Union of Mind and Body. Journal of The History of Philosophy, 9, 159-170, 1971.

Ravaisson F. (1882). La philosophie en France au XIXe siècle. Paris: Hachette.

Schlösser U. (2015). Scepticism and Epistemology. In M. N. Forster, \& C. Gjesdal C. (Eds.), The Oxford Handbook of German Philosophy in the Nineteenth Century (pp. 555-568). Oxford: Oxford University Press.

Sinclair, M. (2017). Habit and time in 19th century French Philosophy. Lemoine between Bergson and Ravaisson. British Journal for the History of Philosophy. Recuperado de: <https://doi.org/10.1080/09608788.2017.1337562>.

Smith, C. U. M., \& Whitaker, H. (Eds.). (2014). Brain, Mind and Consciousness in the History of Neuroscience. Berlin: Springer.

Sommer, R. (1894). Diagnostik der Geisteskrankheiten. Wien: Urban und Schwarzenberg.

Sorley, W. R. (1920). A History of English Philosophy. Cambridge: At the University Press.

Staum, M. S. (1980). Cabanis. Princeton: Princeton University Press.

Stirling, J. H. (1865). The Secret of Hegel. (2 vols.). London: Longman, Green, Longman, Roberts \& Green.

Swain, G. (1977). Le sujet de la folie: naissance de la psychiatrie. Paris: Privat.

Swain, G. (1978). L'aliéné entre le médecin et le philosophe. Perspectives Psychiatriques, 65, 90-99.

Thiel, U. (2015). Self and Sensibility: From Locke to Condillac and Rousseau. Intellectual History Review, 25(3), 257-278.

Trélat, U. (1851). Notice sur Françoise Leuret. Paris: Baillière.

Tuke, D. H. (1873). Illustrations of the Influences of the Mind upon the body in health and disease. Philadelphia: Lea.

Uexküll, Thure von. (Ed.). (1997). Psychosomatic Medicine. München: Urban \& Schwarzenberg.

Wickens, A. P. (2015). A History of the Brain. London: Psychology Press. 


\title{
CLÁSSICOS DA PSICOPATOLOGIA
}

\begin{abstract}
(Albert Lemoine e a epistemologia da psiquiatria)

Em 1862, o filósofo francês Albert Lemoine (1824-1874) publicou um dos primeiros trabalhos sobre a filosofia da psiquiatria e da psicopatologia. Embora criado como um pensador espiritualista nos moldes de Maine de Biran e RoyerCollard, ele tentou reconciliar o relato neurobiológico especulativo da loucura predominante em seu tempo (particularmente entre alienistas interessados em sua medicalização) com uma abordagem mais ampla, que concebeu a mente como um espaço psicológico povoado por forças dinâmicas e elementos também relevantes para a causalidade e o significado da loucura. No debate em curso sobre se a ciência mais apropriada para o estudo da loucura seria a psicologia ou a fisiologia, ele corretamente ficou no meio. Suas opiniões continuam importantes, pois as questões de que ele tratou ainda não foram resolvidas.
\end{abstract}

Palavras-chave: Psiquiatria, epistemologia, século XIX, França, filosofia, análise conceitual

\section{(Albert Lemoine et l'épistémologie de la psychiatrie)}

En 1862, le philosophe français Albert Lemoine (1824-1874) a publié l'un des premiers ouvrages sur la philosophie de la psychiatrie et de la psychopathologie. Malgré le fait d'avoir reçu une formation de penseur spiritualiste selon Maine de Biran et Royer-Collard, il tenta de réconcilier le récit neurobiologique spéculatif de la folie prédominant à son époque (en particulier chez les aliénistes intéressés par sa médicalisation) avec une approche plus large qui conçoit l'esprit en tant qu'espace psychologique peuplé de forces dynamiques et d'éléments qui sont tout aussi pertinents pour la causalité et le sens de la folie. Dans le débat en cours qui essayait de décider si la science la plus appropriée pour l'étude de la folie serait la psychologie ou la physiologie, il se tenait à juste titre au milieu. Ses opinions restent d'ailleurs pertinentes, car les questions abordées par ce philosophe n'ont toujours pas été résolues.

Mots clés: Psychiatrie, épistémologie, Lemoine, $19^{\text {ème }}$ siècle, France, philosophie, analyse conceptuelle

\section{(Albert Lemoine y la epistemología de la psiquiatria)}

En 1862, el filósofo francés Albert Lemoine (1824-1874) publicó uno de los primeros libros sobre la filosofía de la psiquiatría y de la psicopatología. A pesar de haber sido criado como un pensador de la corriente espiritualista, en los moldes de Maine de Biran y de Royer-Collard, intentó reconciliar el relato neurobiológico especulativo de la locura predominante en su tiempo (particularmente entre alienistas 
interesados en su medicalización) con un enfoque más amplio, que concibió la mente como un espacio psicológico poblado por fuerzas dinámicas y elementos también relevantes para la causalidad y el significado de la locura. En el debate en curso sobre si la psicología o la fisiología eran las ciencias más apropiadas para el estudio de la locura, se mantuvo en la mitad. Sus puntos de vista siguen siendo importantes porque los problemas que abordó aún no se han resuelto.

Palabras-clave: Psiquiatría, epistemología, Lemoine, siglo XIX, Francia, filosofía, análisis conceptual

\section{(Albert Lemoine und die Erkenntnistheorie des Psychiatrie)}

Im Jahr 1862 veröffentlichte der französische Philosoph Albert Lemoine (18241874) eines der ersten Bücher zur Philosophie der Psychiatrie und Psychopathologie. Obwohl er ein spiritistischer Denker im Sinne von Maine de Biran und Royer-Collard war, versuchte er, die spekulative neurobiologische Darstellung des Wahnsinns, welche in seiner Zeit vorherrschte (insbesondere unter den Nervenärzten, die an seiner Medikalisierung interessiert waren) mit einem großzügigeren Ansatz zu verbinden. Dieser konzipierte den Verstand als psychologischen Raum, der von dynamischen Kräften und Elementen besetzt ist, die auch für die Kausalität und Bedeutung des Wahnsinns relevant sind. In der anhaltenden Debatte darüber, ob die Psychologie oder die Physiologie die am besten geeignete Wissenschaft für das Studium des Wahnsinns sei, stand er richtigerweise in der Mitte. Seine Ansichten sind bis heute relevant, da die Fragen, die er anging bis heute noch nicht gelöst sind.

Palabras-clave: Psychiatrie, Erkenntnistheorie, Lemoine, 19 Jahrhundert, Frankreich, Philosophie, konzeptionelle Analyse

Citação/Citation: Berrios, G. E. (2018, março). Albert Lemoine and the epistemology of psychiatry. Revista Latinoamericana de Psicopatologia Fundamental, 21(1), 109-123. http:// dx.doi.org/10.1590/1415-4714.2018v21n1p109.8.

Editores do artigo/Editors: Prof. Dr. German E. Berrios

Recebido/Received: 20.1.2018/ 1.20.2018 Aceito/Accepted: 30.1.2018 / 1.30.2018

Copyright: (C) 2009 Associação Universitária de Pesquisa em Psicopatologia Fundamental/ University Association for Research in Fundamental Psychopathology. Este é um artigo de livre acesso, que permite uso irrestrito, distribuição e reprodução em qualquer meio, desde que o autor e a fonte sejam citados / This is an open-access article, which permits unrestricted use, distribution, and reproduction in any medium, provided the original authors and sources are credited. 


\section{CLÁSSICOS DA PSICOPATOLOGIA}

Financiamento/Funding: $\mathrm{O}$ autor declara não ter sido financiado ou apoiado. The author has no support or funding funded to report.

Conflito de interesses/Conflict of interest: $\mathrm{O}$ autor declara que não há conflito de interesses

/ The author has no conflict of interest to declare.

\section{GERMAN E. BERRIOS}

Médico e filósofo pela Universidad Nacional de San Marcos, Lima, Peru; Psiquiatra; Neurologista; Psicólogo; Filósofo; Historiador e Filósofo da ciência (Oxford University, England); Professor de Neuropsiquiatria e de Epistemologia da Psiquiatria (University of Cambridge, England), desde 1976; Neuropsiquiatra e Chefe do Departamento de Neuropsiquiatria do Hospital Addenbrooke, University of Cambridge, por 32 anos; Coordenador do Comitê de Ética em Pesquisa com Humanos na mesma universidade, por vinte anos; Editor Responsável de History of Psychiatry; Autor de 14 livros, incluindo The History of Mental Symptoms, Descriptive Psychopathology since 19th Century (Prêmio Nacional BMA, 1997), A History of Clinical Psychiatry (com Roy Porter), e Delirio (com F. Fuentenebro) e mais de 400 artigos e capítulos de livros; Membro do Royal College of Psychiatrists; da Associação Britânica de Psicologia e da Academia Britânica de Ciências Médicas; Membro Vitalício do Robinson College, Cambridge; doutor Honoris Causa da Universidade de Heidelberg (Alemanha), da Universidade Nacional Mayor de San Marcos (Peru) e da Universidad Autónoma de Barcelona (Espanha); Grão Oficial da Ordem del Sol (Condecoração do Governo Peruano, 2007); prêmio Ramon y Cajal 2008 concedido pela Asociación Internacional de Neuropsiquiatria.

University of Cambridge

Box 189, Hills Road

Cambridge,

UK CB2 2QQ

e-mail: geb11@cam.ac.uk

This is an open-access article, which permits unrestricted use, distribution,

(cc) BY-NC and reproduction in any medium for non-commercial purposes provided the original authors and sources are credited. 